\title{
Images of Needlework: The Category of Memory in Aurora Levins Morales's Remedios
}

\author{
Elena Nakaznaya \\ Associate Professor, \\ Zabaikalsky State University, (Chita, Russia) \\ ynakazna@mail.ru
}

\section{Doi:10.5901/mjss.2013.v4n9p69}

\begin{abstract}
The present paper is devoted to the exploration of Puerto Rican female identity through individual and collective memory in Aurora Levins Morales's prose poetry cycle Remedios: Stories of Earth and Iron from the History of Puertorriqueñas. To preserve the past against oblivion and restore justice the author intertwines personal accounts and historical records, combines archive documents and oral narratives, highlights verbal and non-verbal texts. The stories of the lost ancestors passed through such acts of creation as weaving, knitting, embroidering and sewing are of special interest in the present paper. These acts of non-verbal creation described in Remedios are associated with social, philosophical and other issues and as a result become memorial representations of women in history and culture.
\end{abstract}

Keywords: needlework, feminine identity, cultural memory, individual memory, informative memory, creative memory, non-verbal text.

\section{Introduction}

From time to time we forget and then rediscover silenced pages of our individual or communal past. "The interplay of the present and past in socio-cultural contexts" is defined as cultural memory (Erll \& Nünning, 2008, p. 2). Changes in the system of cultural codes, shifts in the paradigm of "memory-oblivion" and revision of the U.S. national culture model as an amalgamation of ethnic traditions have stimulated interest in the category of cultural memory. Yurii Lotman distinguishes two types of cultural memory: "informative memory" that includes texts that preserve the results of societal activity and factual information and "creative memory" that generates new concepts and actual texts on a certain stage of human development (Lotman, 1992, p. 200). The dynamic character of cultural memory offers "heavily edited versions of the self and its world" (Caldicott \& Fuchs, 2003, p.12). Once silenced, the stories of non-existent marginalized women become actual and important with the changes of our perception of the surrounding world.

Lack of textual evidences about women's contributions makes the author "seek out and read the available nonverbal texts with which people create a life record, whether or not these people ever take up the pen" (Murthy, 2003, p. 641). Analyzing "the heterogeneity of the discursive and non-discursive manifestations of American cultures of memory", Udo J. Hebel points out that women's artifacts function as sites in the circulation of historical and cultural memory (Hebel, 2008, p. 47). This work reveals the role of women's images of needlework in Aurora Levins Morales's book Remedios: Stories of Earth and Iron from the History of Puertorriqueñas and shows how they help the author make women's absences visible in the social struggle against patriarchal rule.

\section{Literature Review}

Traditionally needlework has been always associated with women. Needlework is "the most powerful metaphor of feminine existence" (Zakreski, 2006, p. 16). Being broad and encompassing, the term needlework includes stitching, sewing, knitting, quilting, embroidery, crocheting, tatting, macramé and some other techniques in which women of different cultures and strata of society have been skilful. Throughout its history needlework has been used "either for the most utilitarian of purposes, such as mending or garment construction, or for the most artistic reasons, such as silk embroidery or tapestry work" (Sirna, 2006, p. 9). In addition to practical, social and aesthetic purposes, needlework techniques "travelled with merchants and explorers, creating a legacy of cross-cultural exchange" (Leslie, 2007, p. xii).

Puerto Rican women have always been involved in needlework. Sewing, crocheting and embroidering were "part of Puerto Rican school curriculum taught as early as the second or third grades" (Sanches Korrol, 1983, p.94). In 1900s migration to the continent lead to the increase in the number of women working in the garment industry. Anthologies 
edited by Edna Acosta-Belén (1986), Félix Matos-Rodriguez and Linda C. Delgado (1998), Altagracia Ortiz (1996) and Vicki L. Ruiz and John R. Chávez (2008) focus on women's incorporation into the paid labor force, including home needlework and the garment industry.

\section{Discussion and Findings}

Aurora Levins Morales is a contemporary writer, poet and essayist with diverse cultural backgrounds. She was born in a family of a Puerto Rican mother and a Jewish father whose Ukrainian family were Holocaust survivors. The development of historiographical studies in the USA and dissemination of feminist societal attitudes greatly influenced her creativity. In the late 1980-s - early 90-s she concentrated on the works of Basil Davidson on the history of Africa, Marija Gimbutas on the stages of European civilizations, Mercedes Lopez Baralt and José Juan Arrom on the history of the Antillean Islands, Fernando Picó, Enriqueta Vila Vilar and Angel Lopez Cantos on the history of Puerto Rico. For Aurora Levins Morales, "memory, individual and collective, is clearly a significant site of social struggle" (Levins Morales, 1998a, p.13).

The author worked in the archives, studying scanty historical materials about the fates of those who were subject to colonization. Interest in historiographic works enabled A. Levins Morales to understand the past as the organizing beginning of her literary creativity. As a result, in 1998 she published the book Remedios: Stories of Earth and Iron from the History of Puertorriqueñas that reflected her creative search for restoring her ethnic past and the manifestations of feminine identity in the historical and cultural panorama of society.

In Remedios: Stories of Earth and Iron from the History of Puertorriqueñas A. Levins Morales constructs an alternative history of the marginalized, highlighting the fates of Puerto Rican women. To preserve the past against oblivion and restore justice the author intertwines personal accounts and historical records in a larger context of the struggle against different types of oppression. Levins Morales's "medicinal history" is based not only on archive documents but is inspired by oral narratives and other acts of creation that reflect very emotional, often traumatized women's experience.

According to Aurora Levins Morales, when the sphere of female communication is limited to family and restricted by dominant culture, women's needlecraft products become the most important ways of representing woman's Self, her creativity, personal style, and expressing social concerns. In the prose poetry cycle Remedios needlework is related to weaving, embroidering, knitting and sewing female characters. For A. Levins Morales in the process of needlework everything matters: preparation of fabrics, participants, the process of needlework and the conditions in which it occurs. The writer endows with special meaning each stage of work and connects the image of needlework with other images in the book.

The image of needlework occurs at the initial stage of A. Levins Morales's career as a writer and multilaterally develops in her subsequent works. In her first book Getting Home Alive (1986), written together with her mother Rosario Morales, she researches multiple, fluid female identities. With the help of the sewing metaphor Rosario Morales connects Puerto Rican, Jewish and American parts of her Self: "I ran small running stitches up my scalp, small chain stitches down my face" (Levins Morales, A., and Morales, R., 1986, p. 158). Every stitch is physically palpable and painful and is made with much care as a result of painstaking search, as a reflection of her own thoughts and feelings, as a desire to find her place in the world around her. The daughter joins her mother's attempt to make sewing a revolutionary weapon, invites other women to create their own designs. As Carmen Rivera explains: "Mother and daughter profess a social commitment and solidarity that goes beyond the island, the American continent, or Israel to embrace all humanity in its multiplicity and contradictions" (Rivera, 2002, p. 74). A. Levins Morales continues her mother's fight for the female representation in human history.

From time immemorial, women were engaged in needlework decorating their homes, sewing and knitting for themselves and their families. The process of needlework begins with the manufacture of handicrafts and dyeing fabrics. The prose poem - 4,000: Colors - West Africa is probably one of the most radiant episodes in the cycle Remedios. The process of creation, coloring the fabrics is accompanied by the sun rays. The color palette of fabrics corresponds to all colors of the rainbow. In folklore, rainbow means "transfiguration, heavenly glory, and different states of consciousness" (Cooper, 1978, p. 136). In the process of dyeing fabrics, not only the transformation of the material, but the psychological transformation of thoughts and feelings of their creators is important. What matters is also experiencing the joy of the participation in the process of creation and transformation of the surrounding world, merging with nature. Iridescent colors of fabrics are associated with the preparation for "a flowery quilt" of the American nation that embraces all races and classes.

In the prose poem 1493 to 1511: Leyendas - Puerto Rico A. Levins Morales concentrates the readers' attention on 
the ornament details of the embroidery, which the legendary Puerto Rican girl prepares for her uncle. She "made a special length of cloth $\langle\ldots\rangle$, with zig-zag patterns like the backs of storm clouds or iguanas as a sign of Iguanaboina, the cave from which all weathers come. Between the zig-zags she painted the spiral sign of Guabancex, the storm mother, to keep him safe and powerful" (Levins Morales, 1998, p. 72). Archaic themes and characters of Guanina's embroidery are notable for their rigor and solemnity, the geometric interpretation. All the embroidered pictures are aimed at satisfying men's needs and interests. Zig-zag lines symbolize "lightning, fire from lightning and fecundity. It's an attribute of all storm gods" (Cooper, 1978, p. 198). They must accompany male luck. The cave is "a primal image of shelter" (Tresidder, 2004, p. 91) that protects men from enemies in case of an armed conflict. Semantics of Guanina's images and ornaments of embroidery reflects the distribution of gender roles in patriarchal society, the existence of a universal political structure of male dominance over women. Society with a pre-defined asymmetric distribution of roles polarizes role behavior, prescribing activity and aggressiveness to men and unconditional submissiveness and passivity to women in private and public spheres of life. The image of the Goddess of Guabancex, the storm mother, on the man's clothes appears to protect him, "keep him safe and powerful" no matter what blew other people's way (Levins Morales, 1998, p. 72). In this context, Guanina assumes the role of a defender protecting her people from invaders.

Almira Usmanova, speaking about the role of feminist criticism, connects the non-recognition of women's art with the existence of the opposition of "high - low" art, which, in turn, arose in modern times as a result of cultural stratification along class lines, etc. Decorative arts, crafts (embroidery, etc.) were classified as "low" art (if art at all) and were interpreted not as a free artistic activity, but as labor and family responsibilities of women - as "women's work" (Usmanova, 1999). That's why in the texts of male authors the motif of needlework (sewing, knitting, embroidery) often has a lower nuance, whereas in the works of female authors, including A. Levins Morales's book, the image of needlework is not only linked to domestic work but also performs other functions and, above all, it is one of the ways to approve women's creativity, and return to "Self".

In the prose poem 900 to 1200: Poets of al-Andalus - Muslim Spain the notions of needlework, memory and word are tightly intertwined. Wallada, known in history as the daughter of the murdered minister al-Mushafi and the object of adoration of a famous poet Ibn Zyadun is an extremely talented person. However, her poetry did not earn her fame and prosperity in life. People will remember her verses embroidered on the sleeve of her shirt: "I am made, by God, for glory, and I walk proudly on my own road" (Levins Morales, 1998, p. 43). It signifies her independence and self-sufficiency. She doesn't want to reconcile with the woman's subordinate position within the conventional patriarchal hierarchy. The image of embroidery here is, on the one hand, a memorial embodiment of Wallada's creative talents and, on the other hand, the woman's desire to express herself not through Another, a man - a father or a lover, but through the construction of her own identity, her own creativity.

The connection of the image of needlework with creativity is observed in the works of other American writers of Puerto Rican descent. In the autobiography When I was Puerto Rican (1993) by Esmeralda Santiago embroidering napkins by Negi's grandmother is not just an everyday necessity of running the house, but a way of self-expression of an elderly woman, a noble work that requires much effort, challenging thoughts, concentration of attention, focus and manifestation of creative imagination when designing a pattern.

In the genealogy of her own family A. Levins Morales finds a long line of women whose lives were connected with needlework: relatives on her mother's line, grandmothers and great-grandmothers whose images "become alive" in the prose poem 1934: Needleworkers. The leitmotif detail of the images of seamstresses, immigrant women who had to work in dark rooms for meager salaries to earn for living is alliteration - the repetition of the sounds [s] $и$ [z], that imitate the deafening noise of sewing machines and are confluent with the voice of women' indignation: "But the meaning is the same in their singing and sighing and angry whispers and on the picket signs and leaflets in the streets” (Levins Morales, 1998, p.185). Levins Morales shows that sewing at the garment factory is a mechanic process that suppresses women's individuality. She turns this traditional occupation of immigrant women in an artistic means of expressing a conflict, an unwillingness to tolerate in silence their marginal status in the world that is doubly strange: "male" and "culturally foreign." Immigrant women were forced by poverty to labour at this economically unrewarding and physically exhausting work. Sewing, here, does not signal of womanly modesty and compliance. It is oppressive and uninspiring.

In the prose poem 1950: Threads - New York, Puerto Rico, Illinois A. Levins Morales connects knitting with the notion of fate as a way of life predetermined by a supernatural power and defining principal moments of man's life, the time and circumstances of his death. Women fate deities exist in different cultures (e.g. Greek moirais, Scandinavian norns and valkyries, Anglo-Saxon virdies, Latvian laimas). In Levins Morales's book women, participants of the political struggle for the independence of Puerto Rico are trapped in a prison cell: Ethel Rosenberg knits sweaters for her children, Lolita Lebrón sews cloths at the garment factory, Jane Speed crochets. They all determine the fates of their 
children deprived of maternal care and abandoned to the care of their relatives and neighbors, and husbands left without their wives' care. The work at the garment factory in New York determines Lolita Lebron's fate associated with the ideas of the island's independence. Lolita sees "thread turning on thread, binding one thing to another, and imagines an infinite flag, endless stripes flowing from her needle into the streets" (Levins Morales, 1998, p.195). Needlework is their therapy; it helps them recover from the tragedy of separation from their beloved. They cope with the shock thanks to the comfort of their needlework. Facing the threat of death, repressed on all sides by the circumstances, these women are fighting for their lives and the lives of their loved ones: "turning fear into motion, the needles twist threads into something colourful and warm", they "do not let life unravel from their hands" (Levins Morales, 1998, pp. 194, 196). Twisting threads is not just telling the story about the fates of individual women but also a metaphor for the love of life, the continuation of life, unwillingness to surrender to fate or obey the fatal circumstances. Female characters in this prose poem stand up for an unconventional way of their self-realization, choose the way of their life behavior that is inconsistent with the traditional role ascribed to them by the society, they strive to change their fate and the fate of their people.

Throughout the cycle, the writer strongly emphasizes the relation of the image of needlework to the category of memory. In A. Levins Morales's work vanished civilizations, destroyed cities and villages become the manifestations of psychic disharmony. However, the fragmentary picture of the world acquires its integrity and completeness in women's handicrafts because in the weavings "the universe that conquest shattered is remembered whole" (Levins Morales, 1998, p. 126). According to Levins Morales, the primordial integrity of existence is revealed in female artifacts.

In a number of prose poems Levins Morales emphasizes women's desire to pass down the skills in embroidery and knitting to their daughters. As Sanchez Korrol puts it, the transmission of needlework skills from one generation to another "fortified cultural and community traditions while providing a degree of economic security" (Sanchez Korrol, 1983, p. 95). Levins Morales emphasizes that teaching young women needlework continued the tradition of their ancestors and avoided breaking the threads connecting different generations. (1696: The Weavers of Tayasal - Guatemala).

\section{Conclusion}

Thus, the manifestations of needlework in Remedios suggest that each type of feminine needlework acquires very stable associative relationships: embroidery symbolizes the top of creative female activity, embodies her individual style; knitting serves a sign of fate, sewing is associated with an expression of protest against the foundations of society and the desire to restore justice. The writer explores the famous mythological motif of needlework, enriches it with contemporary sociocultural, philosophical and ethic associations. As a result, this motif is filled with new contents and becomes an important means of expressing the author's idea about the restoration of her ethnic past and "feminine" in history and culture. The images of needlework in works by multicultural authors play a very important role as they enable them to reveal silenced pages of history and connect the parts of their split identities.

\section{References:}

Acosta-Belén, E. (Ed.). (1986). The Puerto Rican Woman: Perspectives on Culture, History, and Society. (2nd.ed). N.Y.: Praeger. Caldicott, Edric \& Fuchs, Anne. (Eds.). (2003). Cultural Memory: Essays on European Literature and History. Oxford: P. Lang. Cooper J.C. (1978). An Illustrated Encyclopaedia of Traditional Symbols. London: Thames \& Hudson Ltd.

Erll, A. (2008). Cultural Memory Studies: An Introduction. In. Erll, A. \& Nünning, A. (Eds.) in collaboration with Young, S. B., Cultural Memory Studies: An International and Interdisciplinary Handbook. (pp. 1-15). Berlin; New York: Walter de Gruyter.

Hebel, U. J. (2008). Sites of Memory in U.S.-American Histories and Cultures. In. Erll, A. \& Nünning, A. (Eds.) in collaboration with Young, S. B., Cultural Memory Studies: An International and Interdisciplinary Handbook. (pp. 47-60). Berlin; New York: Walter de Gruyter.

Leslie, C. A. (2007). Needlework Through History: An Encyclopedia. Westport, Conn. \& London: Greenwood Press.

Levins Morales, A., and Morales, R. (1986). Getting Home Alive. Ithaca, N.Y.: Firebrand Books.

Levins Morales, A. (1998a). Medicine Stories: History, Culture and the Politics of Integrity. Cambridge, MA.: South End Press.

Levins Morales, A. (1998). Remedios: Stories of Earth and Iron from the History of Puertorriqueñas. Boston: Beacon Press.

Lotman Y. M. (1992). Memory in a Cultural Light. Selected Articles in 3 Volumes. (pp. 200-202). Tallinn: "Alexandra" Press, Vol.1.

Matos-Rodriguez, F. and Delgado, L. C. (Eds.). (1998). Puerto Rican Women's History: New Perspectives. Armonk, N.Y.: M.E. Sharpe.

Murphy, A. M. (2003). The Theory and Practice of Counting Stitches as Stories: Material Evidences of Autobiography in Needlework. Women's Studies: An Interdisciplinary Journal 32.5: 641-655.

Ortiz, A. (Ed.). (1996). Puerto Rican Women and Work: Bridges in Transnational Labor. Philadelphia: Temple Univ. Press.

Rivera, C. (2002). Kissing the Mango Tree: Puerto Rican Women Rewriting American Literature. Houston, TX.: Arte Público Press.

Ruiz, V. L. and Chávez, J. R. (Eds.). (2008). Memories and Migrations: Mapping Boricua and Chicana Histories. Urbana: University of 
Illinois Press.

Sanchez Korrol, V. E. (1983). From Colonia to Community: The History of Puerto Ricans in New York City, 1917-1948. Westport, Conn., \& London: Greenwood Press.

Sirna, C. G. Forward by Shay Pendray. (2006). In Praise of the Needlewoman: Embroiderers, Knitters, Lacemakers, and Weavers in Art. London \& N. Y.: Merrell.

Tresidder, Jack. (Ed.). (2004). The Complete Dictionary of Symbols in Myth, Art and Literature. London: Duncan Baird Publishers.

Usmanova A. (1999), Bezzashhitnaja Venera: razmyshlenija o feministskoj kritike istorii i teorii iskusstva // da Z'mestu, №3(4). /I Усманова А. Беззащитная Венера: размышления о феминистской критике истории и теории искусства // да Зьместу. 1999. - №3(4). Retrieved March 23, 2013 from http://arche.bymedia.net/3-1999/usma399.html

Zakreski, P. (2006). Representing Female Artistic Labour, 1848-1890: Refining Work for the Middle-class Woman. Aldershot, Hants, England; Burlington, VT: Ashgate Pub. Company. 